\title{
A Model for Assessing and Enhancing Efficiency of E- learning systems
}

\author{
Mohamed Attia \\ Information System \\ Department, Faculty of \\ Computer and Information, \\ Helwan University, Egypt
}

\author{
Manal A. Abdel-Fattah \\ Information System \\ Department, Faculty of \\ Computer and Information, \\ Helwan University, Egypt
}

\author{
Sayed Abd El-Gaber \\ Information System Department, \\ Faculty of Computer \\ and Information, \\ Helwan University, Egypt
}

\begin{abstract}
There are few studies on evaluation of Learning Management Systems (LMS) within higher educational organizations. Moreover, most of earlier studies have many shortages in its evaluation methods. For example, it focuses on the unilateral view of the evaluation method; it doesn't show weights for each different criterion effecting LMS and doesn't rank its importance. This research proposes an evaluation criteria model that avoids all shortcomings on earlier studies as follows: By evaluating the LMS on multidimensional way, discovering new relations between different criteria, determining weights for each criterion and ranking most critical criteria effecting on LMS. The evaluation criteria consist of six dimensions technology, system and service quality, communication, effectiveness of content, instructors and students dimensions. Each dimension encompasses of set of other criteria. A survey questionnaire based on these evaluation criteria and its relations has been applied to 100 learners of the British university of Egypt, 125 learners on Helwan University and set of instructors at both universities. Then, verifying questions by holding a meeting with set of experts. Descriptive statistics were run to analyze the collection of data, delete outlier of it and test data reliability. Collective of Artificial intelligence (AI) methods are used for ranking each criterion and Dempster-Shafer theory is used to compare between different results of AI for obtaining the most critical ten ranking criteria based on achieving satisfaction for both students and instructors. The results of research showing that communication dimension, responsiveness and availability of instructors on LMS and degree of interactive courses are the highest three critical criteria for British university. It also sheds light on the attitude of instructors and students towards technology in addition to the easy access of any services or content and responsiveness of instructors on Helwan University.
\end{abstract}

\section{General Terms}

Learning management system (LMS), Artificial Intelligence (AI)

\section{Keywords}

E-learning - ranking criteria - e-learning evaluation- system Quality-Egyptian universities

\section{INTRODUCTION}

E-learning systems have been developed by different higher education institutions around the world. Consequently, there are different evaluations for each system [2]. This research attempts to introduce a comprehensive e-learning evaluation criteria based on reviewing the criteria that suitable to Egyptian universities.

Egyptian e-learning systems using specific functions with limited capabilities. Consequently, this research proposes evaluation criteria that suitable to LMS inside Egyptian universities, according to most of e-learning systems in higher education. Dimensions of evaluation consist of six dimensions (1) technology dimension, (2) system and service quality, (3) communication,

(4) effectiveness of content, (5) instructors, (6) students dimension $[1,2]$.

The paper is organized as follows: both Sections 2 and 3 are determined criteria that effect on efficiency of LMS inside Egyptian universities and determine the relationship between different factors

Then, determining methodology of the work of the research from data collection through the questionnaire instrument and data analysis methods by artificial intelligence and Dempster-Shafer theory through section 4 .

Section 5 start applying data collection and analysis methods for both British and Helwan university. Data collecting from the questionnaire will be tested for reliability and explanatory factor analysis have been occurred using collective of AI methods for ranking criteria based on satisfaction of students and instructors. Then, get the optimal and heights weights of criteria that effect on LMS using the Dempster-Shafer theory.

\section{LITERATURE REVIEW}

According to many of the prior studies, there is little researchers determining criteria effect on LMS in a general scale. Most of previous studies focus on unilateral view of evaluation methods. Many researchers focus on the role of information technology infrastructure services in terms of the success of eLearning systems [14]; While others have studied only the human criterion of e-learning systems [20]. Douglas et.al. Dealt with the effectiveness of e-learning course materials only. In addition, there are other technical issues such as system \& service quality and Internet quality that have a significant effect on the effectiveness of an LMS [15].

Also from reviewing all individual evaluation criteria may yield convenient solutions. However, for effective elearning, there is a need for multidimensional evaluation criteria which comprises of all above dimensions. This paper introduces the most critical criteria on multidimensional view that is suitable to Egyptian universities. According to the review of many e-learning 
systems and its structure in Egyptian universities to both private and public universities; the most of e-learning systems in any higher education affected by six basic dimensions technology dimension, system and service quality, communication, effectiveness of content, instructors and students dimension [2,3]. Each dimension has been evaluated through other criteria as shown in Figure 1 .

\subsection{Technology dimension.}

2.1.1 Easy usage of technology [3]

\subsubsection{Accessibility [3]}

\subsection{Communication dimension.}

2.2.1 Broadband connection [22]

\subsubsection{Download rate [17]}

\subsection{System and service quality}

2.3.1 Structure of services [17]

\subsubsection{System error tracking [23]}

\subsubsection{Services quality}

\subsection{Effectiveness of Content}

2.4.1 Interactive courses $[17,24]$

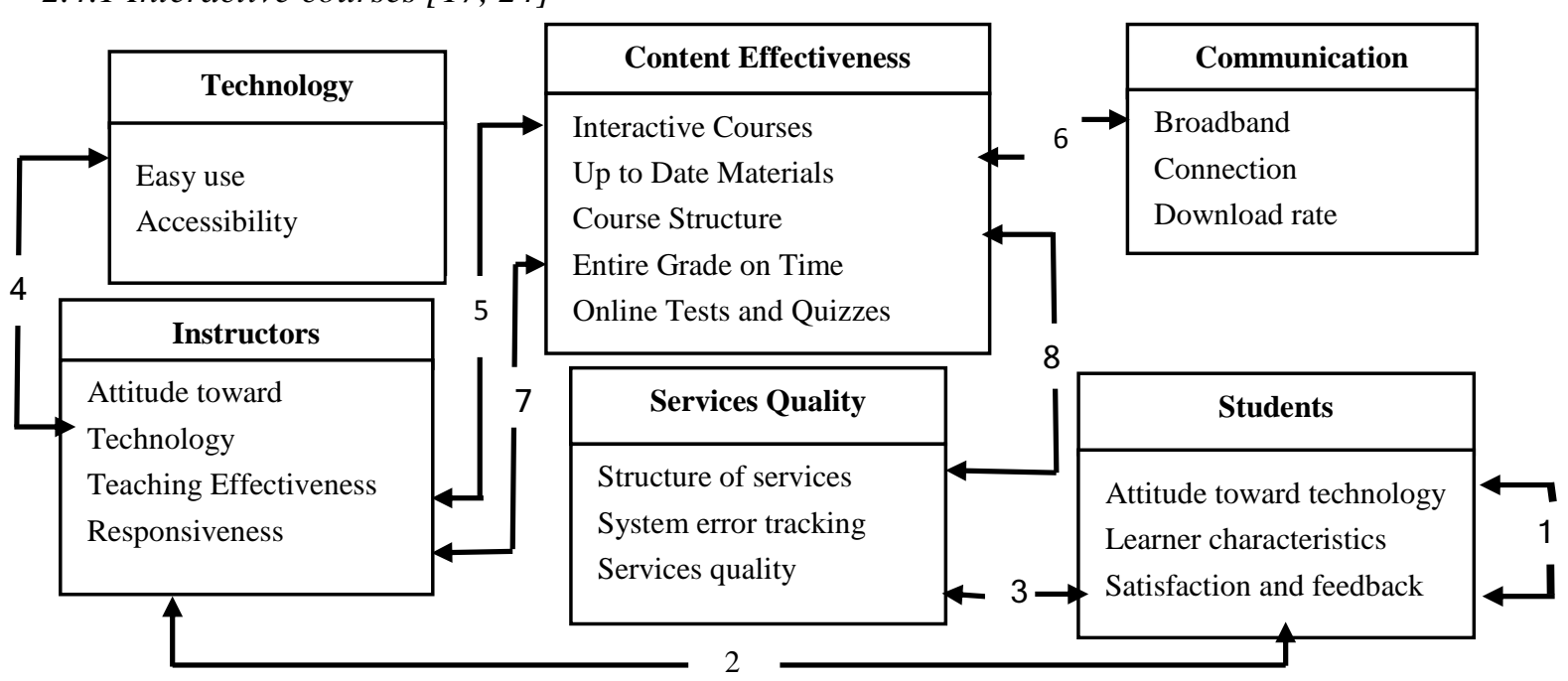

Figure 1: Multidimensional criteria of evaluating LMS and its relations on Egyptian universities

\subsection{Description of relations}

There are relations between different criteria that is already identified in previous research like relation 1,2 and 3. Also there are new relations identified and proved through this research. Relations could be divided into eight relations as shown in fig 1.

Relation 1: Positive relationship between the attitude of the students toward technology used on LMS and their satisfaction level [1].

Relation 2: Responsiveness of instructors and satisfaction level of students [30].

Relation 3: Quality of services on LMS and satisfaction level of students [1].
2.4.2 Up to date materials [25]

2.4.3 Course structure [26]

2.4.4 Entire grade on time [25]

2.4.5 Online tests \& quizzes [25]

\subsection{Instructor Dimension}

2.5.1 Attitude toward technology

\subsubsection{Teaching Effectiveness [24]}

\subsubsection{Responsiveness [28]}

2.6 Student dimension

2.6.1 Attitude toward technology

\subsubsection{Learner characteristics [29]}

\section{CORRELATION BETWEEN CRITERIA THAT EFFECT ON EGYPTION LMS}

According to a literature review of previous researches on evaluating e-learning systems and meeting with experts on this field, there are relations between different criteria. 


\section{RESEARCH METHODOLOGY}

In this research, quantitative methods have been used to collect data. Gathering data from students and instructors about their observations of LMS in regards to their satisfaction level. A survey instrument questionnaire based on proposed evaluation criteria and its relations as shown in figure 1 has been created. Then it is referred to a group of experts via meeting discussion to verify the questions. The aim of this meeting is to verify questions based on achieving high efficiency of LMS. A total number of seven experts in the field of information systems and decision support department have been asked to estimate whether each dimension inside the model is vital or not vital for achieving high quality LMS. Two of the experts are from the faculty of computer science, Information Systems department, Helwan University, Egypt; two from the Management Information Systems department, future academy, Egypt; Two of the experts are from the faculty of computer science, Information Systems department, British University, Egypt; one from the decision support department, Institute of Statistical Studies and Research, Cairo university.

\subsection{Data collection}

The survey instrument questionnaire applied on evaluation criteria of LMS and its relation as shown in figure 1 and verifying questions through feedback gained from meeting with experts. Questionnaires have been applied to 100 undergraduate levels 2, British universities ,Egypt, 125 undergraduate level 3, Helwan University, Egypt and set of instructors on both two universities. This sample is chosen based on the most students and instructors who are active on LMS. In this way of the survey instrument is used, since there are a large number of samples from whom information and opinions are needed. Questionnaires on this research were tested by asking a sample of students and instructors and analyze the results for obtaining clear information. Information on questionnaires cannot be immediately clarified for a confused respondent. Questionnaires must be very clearly written and must leave little room for misunderstanding; therefore, closed-ended questions tend to be more commonly used as shown in appendix B. To enable the analyst to clearly separate facts from opinions. Designing close ended question consisting of 27 questions based on evaluation criteria and its relations and verifying those questions by gaining feedbacks on meeting with a group of experts. The first sixteen answers of the questions and answer of the last question rang between poor, average, good and very good choice, and the other ten questions answers rang between yes or no choices. These twenty-seven questions have been measured six dimensions consist of 17 criteria as shown in appendix A. Each question represents criterion or set of criteria.

\subsection{Data Analysis}

Examining a collection of data from designed questionnaires using descriptive statistical methods, statistical Package (SPSS) version 21 Windows software program to analyze the data collected. In order to validate the proposed LMS evaluation criteria and deleting outlier of data for more consistency and a number of validity and reliability tests have been applied to data collected from BUE and Helwan universities to assess the internal consistency of the items representing each factor using Cronbach's alpha than calculating the general reliability indicator for data collection.

\subsubsection{Reliability analysis}

In order to determine the reliabilities of the criteria and evaluating the internal consistency of the criteria, we used Cronbach's alpha. All the criteria have high values of Cronbach's alpha results which are around 0.7 being close to one. Since Cronbach's alpha evaluates how well the items of a criterion measure a single one-dimensional latent construct; a high value closer to one indicates that the items consisting the criterion can measure the same underlying structure meaning they form a reliable criterion and they are consistent in between the other items in the factor [12].

\subsection{Applying Collective Artificial Intelligence Methods Based On DTREG Predictive Modelling Software}

The main idea of predictive software modeling is the integration of multiple sources of AI methods to reach to multidimensional view and obtain the final optimum ranking criteria effect on LMS .Dtreg accepts a dataset containing of number of rows with a column for each variable. One of the variables is the "target variable" which is overall satisfaction of students and instructors of using an LMS of Helwan and BUE universities whose value is to be modeled and predicted as a function of the "predictor variables". DTREG analyzes the data and generates a model showing how best to predict the values of the target variable based on the values of the predictor variables.

\subsubsection{Using decision tree Method.}

A decision tree can be used to predict the values of the target variable based on the values of the predictor variables. To determine the predicted value of a row, begin with the root node. Then decide whether to go into the left or right child node based on the value of the splitting variable.

\subsubsection{Support vector machine (SVM).}

"Support vector machines are supervised learning models with associated learning algorithms that analyze data used for classification and regression analysis". Given a set of training examples predictors and target variable [7].

\subsubsection{Multilayer perception network (MLP)}

The goal of using this method is to find the set of weight values that will cause the output from the neural network to match the actual target values as closely as possible [10]

\subsubsection{Gene expression programming (GEP)}

"Gene expression programming searches for the "optimal" solution by evolving the population generation after generation. Individuals in the new generation are produced based on those in the current one. Three genetic operators are usually used to produce the new generation. They are Reproduction, Crossover, and mutation [9]" 


\subsubsection{A radial basis function ( $R B F)$}

" The basic idea is that a predicted target value of an item is likely to be about the same as other items that have close values of the predictor variables $[6,7] "$

\subsection{Dempster-Shafer theory}

Theory presents the concept of the ignorance, also assigns certain value to it. In real life, data fusion is required where multiple sources of information are combined to inform the best judgment of the situation. The main merit from information accumulation is the ability to simply and summarizes the collected data to gain the benefits of multiple sources of information. There are many types of link sources of information, which is called "Combination rules [11]". Five artificial intelligence methods are used in this study and obtaining different ranking factors with different weight for each criterion; therefore, it is an essential need to apply Dempster Shafer theory to obtain the final optimum ranking criteria effect on LMS. Dempster-Shafer theory combines information from different sources of artificial intelligence methods as input to a total conclusion and final optimum ranking factors. By considering each artificial intelligence method result as an expert represents the relative importance of each feature to determine which optimal feature number that give an optimal generalization ability.

\subsection{A proposed model for evaluating the criteria of e-learning systems}

A proposed model for evaluating criteria inside elearning systems of Egyptian universities. The Process of evaluation of the model occurring through six phases as shown in figure 2 as follow:

\section{Phase I: Criteria determination.}

Phase one determines the dimensions of evaluation that suitable to the Egyptian universities LMS that cover all perspectives of e-learning systems as shown in Figure 1.

\section{Phase II: Planning.}

It defines audiences of research (students-instructors) who are evaluating e-learning systems, then determines survey questionnaires based on evaluation criteria and its relations as shown in Figure 1. Finally, questions have been verified by meeting some experts.

\section{Phase III: Data collection.}

The data has been collected and prepared before analysis by designated questionnaires which have been applied on 100 learners of British university and 125 learners of Helwan university and some instructors on both universities.

Phase IV: Descriptive and reliability analysis.

After collecting data from the previous phase, data have been analyzed through two steps: -

Descriptive analysis of data for cleaning data and deleting outlier of it as shown in table 1 .

Data have been checked for reliability and determination of the assurance level as shown in table 1 .

Phase V: Ranking and measuring data using AI methods.

Collection of artificial intelligence methods based on Dtreg modelling software. Decision tree, SVM ,MLP ,GEP and RBF methods have been applied for collecting data as shown in table 2 , in order to measure weight for each criterion and rank it based on satisfaction for both students and instructors. 


\section{Phase I : Dimensions determination}

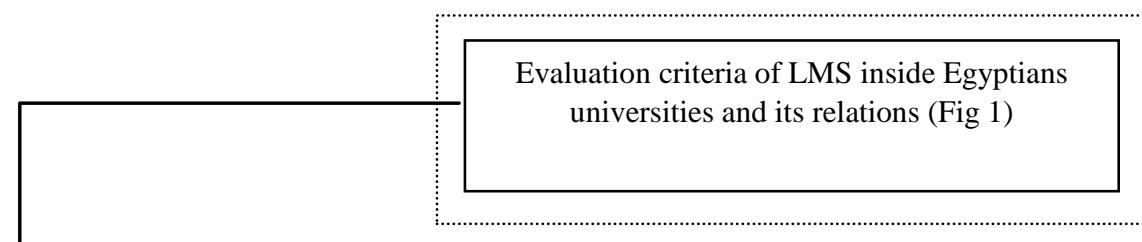

Phase II: Planning

\section{Phase III: Data}

Phase IV: Reliability

Analysis
1- Target Audience determination

2- Determine survey questionnaires
Data Collection through designated questionnaires from students and instructors
Phase VI: Dempster-Shafer theory for obtaining optimal final ranking criteria
Phase V: Ranking

criteria

Using Al methods

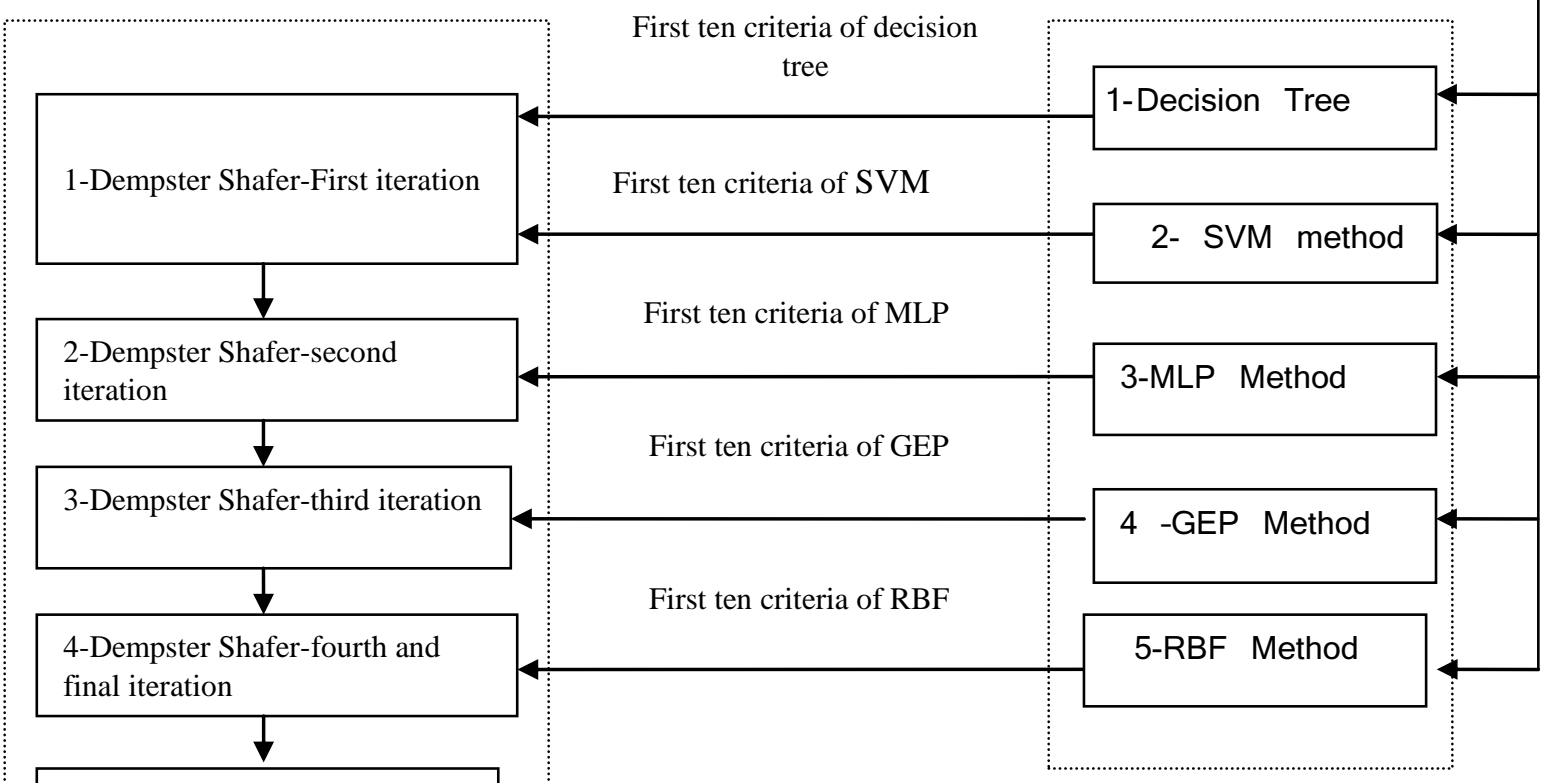

Final Optimal Ranking criteria effect on (LMS)
Figure 2: Depicts the proposed evaluation model that applied to the cases study

(Synthesized by the author).
Phase VI: Dempster-Shafer theory for getting the optimal final ranking criteria.

The Dempster Shafer theory has been applied as a result of obtaining different rank and weight for each criterion resulted from applying five AI methods. Dempster theory combines multiple sources of information to summarize the collected data as shown in equation (1). Data has been combined and computed to get final weight and rank for each criterion through four iterations as follow: -

- First iteration: Basic Input is the highest weight of ten criteria resulted from applying both decision tree methods and support vector machine method as shown in table 3 . 
The output of this iteration is the highest weight of ten criteria resulted from applying Dempster theory on two input AI method results.

- Second iteration: Input: The first weight of ten criteria resulted from first iteration and first weight of ten criteria resulted from applying the multilayer perception method.

Output is the first ten weights of criterion resulted from applying Dempster theory on results of first phase results with MLP method results.

- Third iteration Input: Is the first weight of ten criteria resulted from second iteration and first ten criterion weights resulted from applying gene programming method.

Output is the first ten criteria resulted from applying Dempster theory on input data.

- Fourth and final iteration Input: Is the first weight of ten criteria resulted from third iteration and first ten criterion weights resulted from applying the radial basis function.

Output is the first ten criteria resulted from applying Dempster theory on input data. Results of iteration four are the Final Optimum Ranking criteria effect on (LMS) on both BUE and Helwan universities based on satisfaction of students and instructors.

\section{APPLYING THE PROPOSED MODEL TO THE CASE STUDIES BRITISH AND HELWAN UNIVERSITY.}

The British University of Egypt (BUE) is one of the private Egyptian universities and Helwan University of Egypt (HU) is one of governmental university that depends on learning management system in its educational process. Such that uploading lecture, exams, assignments and results of exams.

\subsection{Analysis of collecting data}

The survey instrument questionnaires were distributed to a total of 100 undergraduate students at British universities of Egypt, BUE, and 125 undergraduate students of Helwan University. All respondents are active users of learning management system as a supportive tool to the courses they are enrolled. Loading data collected by survey instrument from designing questionnaires as shown in appendix B.

Descriptive statistical methods in the Statistical Package (SPSS) version 21 were run to clean Data collection and delete the outlier of it. And a number of validity and reliability tests have been applied on data to assess the internal consistency of the items representing each factor using Cronbach's alpha then calculating the general reliability indicator for collecting data as shown in table 1 .

\subsection{Ranking criteria based on artificial intelligence methods}

After making sure of reliability of data and deleting outlier of data. Loading data in Dtreg predictive modelling software and determine the predictors and target variables. Questionnaires consist of 26 questions measuring 17 criteria. Twenty-six variables represent predictor variables and the target variable is the last variable, that representing the overall satisfaction of students and instructors.

Then applying collective of artificial intelligence methods for ranking factors. Start analysis data using Dtreg predictive modelling software by using a decision tree, SVM, MLP, GEP and RBF methods. Each method has been produced the most ten important criteria in a ranked way based on achieving the highest score for the target variable as shown in table 2. Each variable name representing on Appendix A.

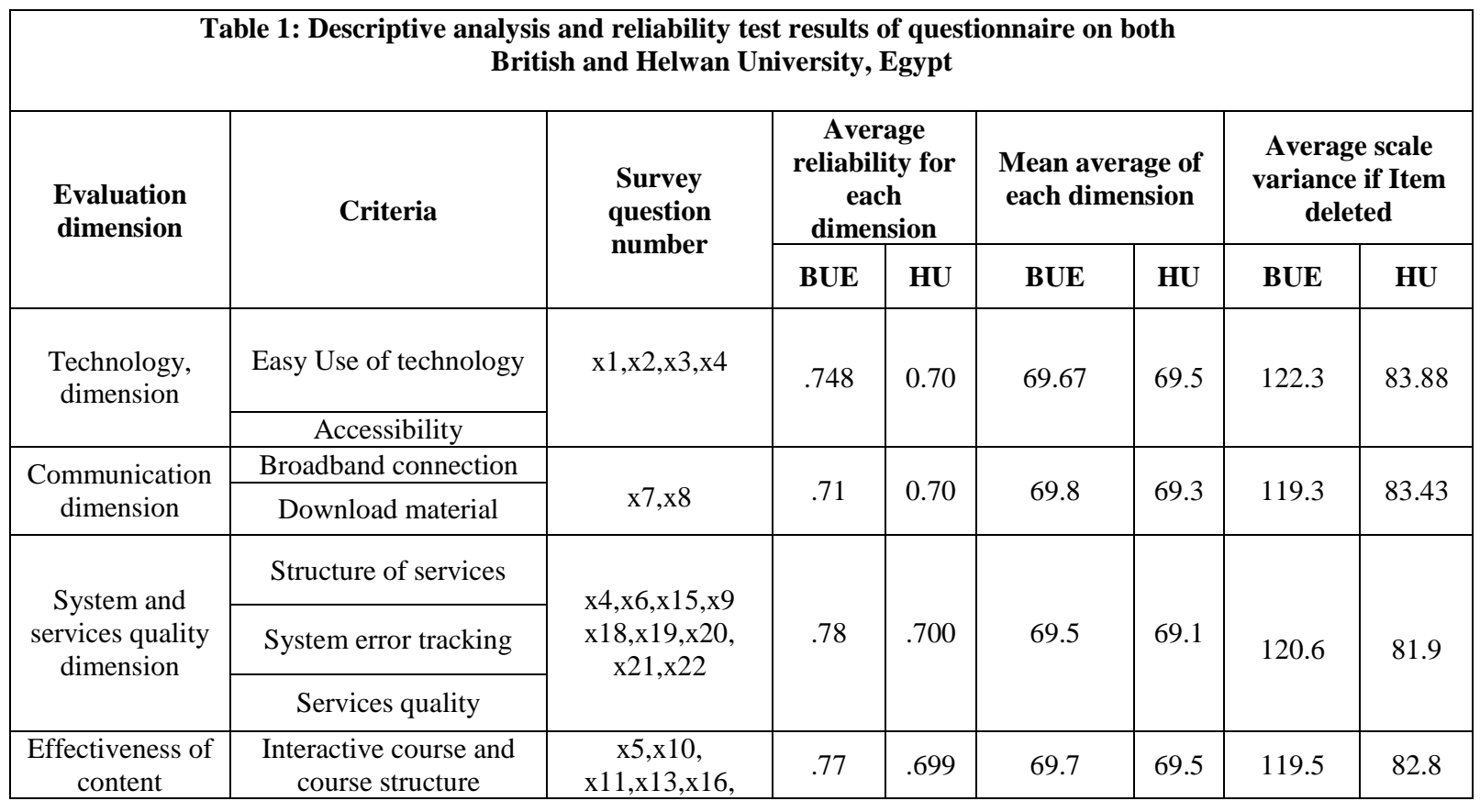




\begin{tabular}{|c|c|c|c|c|c|c|c|c|}
\hline \multirow[t]{3}{*}{ dimension } & Up to date materials & \multirow{3}{*}{$\begin{array}{c}\mathrm{x} 23 \\
\mathrm{x} 24, \mathrm{x} 25, \mathrm{x} 26\end{array}$} & & & & & & \\
\hline & Entire grade on time & & & & & & & \\
\hline & Online tests \& quizzes & & & & & & & \\
\hline \multirow{3}{*}{$\begin{array}{l}\text { Instructor } \\
\text { dimension }\end{array}$} & Teaching effectiveness & \multirow{3}{*}{$\begin{array}{c}\mathrm{x} 1, \mathrm{x} 2, \mathrm{x} 5, \mathrm{x} 11, \\
\mathrm{x} 12, \mathrm{x} 16, \mathrm{x} 25, \\
\mathrm{x} 26\end{array}$} & \multirow{3}{*}{.760} & \multirow{3}{*}{.688} & \multirow{3}{*}{69.5} & \multirow{3}{*}{69.6} & \multirow{3}{*}{119.9} & \multirow{3}{*}{80.2} \\
\hline & $\begin{array}{l}\text { Responsiveness and } \\
\text { availability }\end{array}$ & & & & & & & \\
\hline & $\begin{array}{l}\text { Attitude toward } \\
\text { technology }\end{array}$ & & & & & & & \\
\hline \multirow{3}{*}{$\begin{array}{c}\text { Student } \\
\text { dimension }\end{array}$} & $\begin{array}{l}\text { Attitude Toward } \\
\text { technology }\end{array}$ & \multirow{3}{*}{$\mathrm{x} 1, \mathrm{x} 2, \mathrm{x} 14$} & \multirow{3}{*}{.745} & \multirow{3}{*}{69.6} & \multirow{3}{*}{69.7} & \multirow{3}{*}{69.5} & \multirow{3}{*}{121.8} & \multirow{3}{*}{82.05} \\
\hline & Student's characteristics & & & & & & & \\
\hline & Feedback of students & & & & & & & \\
\hline \multirow{2}{*}{\multicolumn{3}{|c|}{$\begin{array}{l}\text { Reliability statistics of data collection on British university } \\
\text { (BUE) }\end{array}$}} & \multicolumn{2}{|c|}{$\begin{array}{l}\text { Cronbach's } \\
\text { Alpha }\end{array}$} & \multicolumn{4}{|c|}{$\begin{array}{l}\text { Cronbach's } \\
\text { Alpha based on standardized items }\end{array}$} \\
\hline & & & \multicolumn{2}{|c|}{.771} & \multicolumn{4}{|c|}{.809} \\
\hline \multirow{2}{*}{\multicolumn{3}{|c|}{$\begin{array}{l}\text { Reliability statistics of data collection on Helwan University } \\
\qquad(\mathrm{HU})\end{array}$}} & \multicolumn{2}{|c|}{$\begin{array}{l}\text { Cronbach's } \\
\text { Alpha }\end{array}$} & \multicolumn{4}{|c|}{$\begin{array}{c}\text { Cronbach's } \\
\text { Alpha based on standardized items }\end{array}$} \\
\hline & & & \multicolumn{2}{|c|}{.705} & \multicolumn{4}{|c|}{.749} \\
\hline
\end{tabular}

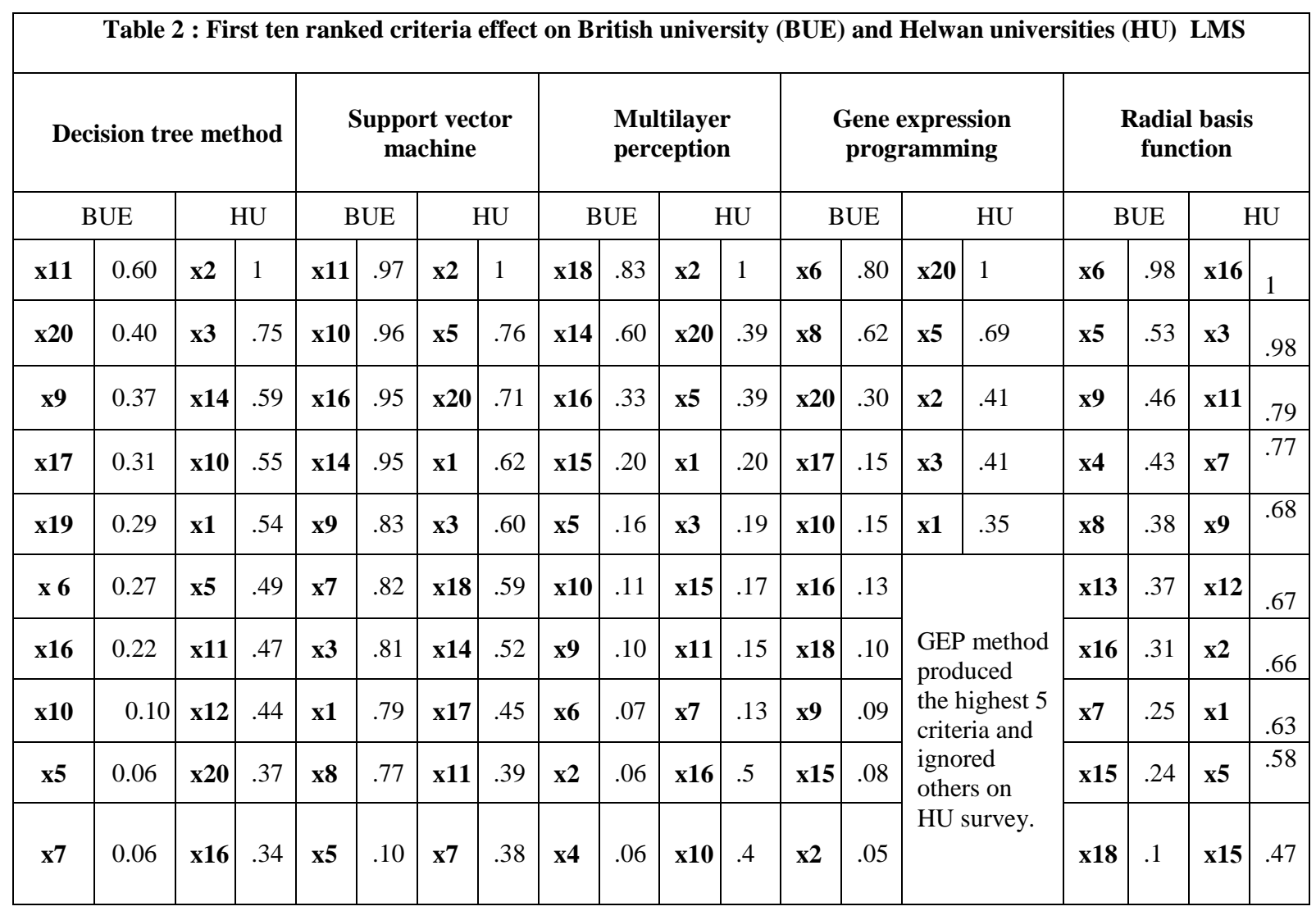

Each artificial intelligence method determines major criteria and its weight as shown in table 2 that control the overall quality of BUE and HU learning management system based on achieving students and instructor's satisfaction. Table 2 shows that each method has its own results and different ranking criteria. Consequently, the problem is there were different ranking criteria and different weights for each criterion. Which one of these methods is the most suitable and optimal solution for ranking these criteria.
Therefore, it is applicable for a generalization of probability theory.

\subsection{Applying Dempster- Shafer theory.}

Computing general importance weight and final ranking degree for each criterion effecting on learning management system by applying Dempster-Shafer theory. Dempster depends on comparing each criteria weight on artificial intelligence method with corresponding criteria probability on other method. And assigns a certain value of ignorance by 
representing it as quite symbol $\Theta$ and its value by default determined on theory as 0.1 . The basic proposition of the

Dempster -Shafer theory that sources used must be independent. Dempster introduces his combination rule (for two sources) in equation 1.

$$
m^{1.2}(c)=\frac{\sum_{A \cap B=C} m^{1}(A) m^{2}(B)}{\sum_{A \cap B \neq \varnothing} m^{1}(A) m^{2}(B)}
$$

\section{Equation 1 [31]}

\section{Assumptions of Dempster Shafer theory:}

- $\mathrm{m}(c)^{1}$ Is the generated judgmental probabilities or the normalized relative importance weight of The first artificial intelligence method.

- $\mathrm{m}(c)^{2}$ Is the generated judgmental probabilities or the normalized relative importance weight of The second intelligence method.

- $\mathrm{A} \cap \mathrm{B}=\mathrm{C}$ mean that there are corresponding criteria on both two methods and the intersection of the product criterion weight of first method $m^{1}$ (A) With the corresponding criterion on the second method $\mathrm{m}^{2}$ (B) Is equal value not nothing.

- $\quad \mathrm{A} \cap \mathrm{B} \neq \varnothing \quad$ mean that all values result from product weights of the first method with the second method including product weights of two methods weights with ignorance $\Theta$ equal value.

- Any conflict between the two-artificial intelligence method, consider zero and any variable coincide with uncertain considered the value of product variable with uncertainty value.

Finally, after applying equation (1) of computation weight for each criterion based on two methods of artificial intelligence method results. Obtaining the highest ten weights of criteria and repeat equation (1) on this result with highest ten weights of third artificial intelligence method and so on until reaching to the last method weights. In the final iteration getting the most critical ten ranking criteria effecting on LMS based on satisfaction of students and instructors.

\subsubsection{Applying Dempster theory on British university $L M S$.}

Table 3: First iteration of computing first ten criteria weights on decision tree with corresponding criteria on support vector machine results on BUE

\begin{tabular}{|c|c|c|c|c|c|c|c|c|c|c|c|c|c|}
\hline & \multicolumn{13}{|c|}{ First ten criteria of Decision tree weights $m^{1}(\mathrm{~A})$} \\
\hline \multirow{13}{*}{ 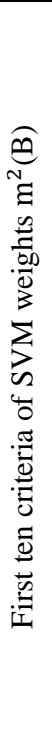 } & \multirow{2}{*}{\multicolumn{2}{|c|}{$\begin{array}{l}\text { Criteria } \\
\text { weight }\end{array}$}} & $\mathbf{x 1 1}$ & $\mathbf{x 2 0}$ & $\mathbf{x 9}$ & $\mathbf{x 1 7}$ & $\mathbf{x 1 9}$ & x6 & $\mathbf{x 1 6}$ & $\mathbf{x 1 0}$ & $\mathbf{x 5}$ & $\mathbf{x} 7$ & $\Theta$ \\
\hline & & & 0.60 & 0.40 & 0.37 & 0.31 & 0.29 & 0.27 & 0.22 & 0.100 & 0.06 & 0.06 & .1 \\
\hline & $\mathbf{x 1 1}$ & .97 & .58 & - & - & - & - & - & - & - & - & - & .097 \\
\hline & $\mathbf{x 1 0}$ & .96 & - & $\ldots$ & - & - & - & - & $=$ & .096 & - & - & .096 \\
\hline & $\mathbf{x 1 6}$ & .95 & - & - & - & - & - & - & .20 & - & - & - & .095 \\
\hline & $\mathbf{x 1 4}$ & .95 & - & - & - & - & - & - & - & - & - & - & .095 \\
\hline & x9 & .83 & - & - & .3 & - & - & - & - & - & - & - & .083 \\
\hline & $\mathbf{x} 7$ & .82 & - & - & - & - & - & - & - & - & - & .04 & .082 \\
\hline & $\mathbf{x} 3$ & .81 & - & - & - & - & - & - & - & - & - & - & .081 \\
\hline & $\mathbf{x 1}$ & .79 & - & - & - & - & - & - & - & - & - & - & .079 \\
\hline & $\mathbf{x 8}$ & .77 & - & - & - & - & - & - & - & - & - & - & .077 \\
\hline & x5 & .10 & - & - & - & - & - & - & - & - & .006 & - & .01 \\
\hline & $\Theta$ & .1 & .06 & .04 & .03 & .03 & .02 & .02 & .02 & .01 & .006 & .006 & .01 \\
\hline
\end{tabular}




$$
\begin{gathered}
\mathrm{x} 1=\frac{.079}{.58+.09+.2+.3+.04+.006+}=\frac{.079}{2.2}=.035 \\
.09+.09+.09+.09+.08+ \\
.08+.08+ \\
.07+.07+.01+.06+.04+.03+.03+ \\
.02+.02+.02+.01+.006+
\end{gathered}
$$

$$
\begin{aligned}
& \mathrm{X} 3=\frac{.08}{2.2}=.036 \\
& \mathrm{X} 8=\frac{.077}{2.2}=.035 \\
& \mathrm{X} 14=\frac{.095}{2.2}=.04 \\
& \mathrm{x} 20=\frac{.04}{2.2}=.018
\end{aligned}
$$

$$
\begin{aligned}
\mathrm{X} 6 & =\frac{.02}{2.2}=.009 \\
\mathrm{X} 10 & =\frac{.09+.09+.01}{2.2}=.08 \\
\mathrm{X} 17 & =\frac{.03}{2.2}=.013
\end{aligned}
$$

$$
\begin{aligned}
& \mathrm{X} 7=\frac{.04+.08+.006}{2.2}=.05 \\
& \mathrm{X} 11=\frac{.58+.09+.06}{2.2}=.33 \\
& \mathrm{X} 19=\frac{.02}{2.2}=.009
\end{aligned}
$$

\begin{tabular}{|c|c|c|}
\hline $\begin{array}{c}\text { Criterion :1 } \\
\text { X8 } \\
\end{array}$ & \begin{tabular}{|l|} 
Criterion :2 \\
X5 \\
\end{tabular} & $\begin{array}{c}\text { Criterion:3 } \\
\text { X9 } \\
\end{array}$ \\
\hline $\begin{array}{l}\text { Communication } \\
\text { Dimension. }\end{array}$ & $\begin{array}{c}\text { Degree of } \\
\text { instructor's } \\
\text { responsiveness } \\
\text { toward } \\
\text { entering grades } \\
\text { on time. }\end{array}$ & $\begin{array}{l}\text { Services quality } \\
\text { and Interactive } \\
\text { courses. }\end{array}$ \\
\hline $\begin{array}{c}\text { Criterion :4 } \\
\text { X16 } \\
\end{array}$ & $\begin{array}{c}\text { Criterion :5 } \\
\text { X18 } \\
\end{array}$ & $\begin{array}{c}\text { Criterion :6 } \\
\text { X13 } \\
\end{array}$ \\
\hline $\begin{array}{c}\text { Degree of } \\
\text { instructors } \\
\text { Responsiveness }\end{array}$ & $\begin{array}{l}\text { System error } \\
\text { tracking }\end{array}$ & $\begin{array}{c}\text { Online Tests \& } \\
\text { Quizzes }\end{array}$ \\
\hline $\begin{array}{c}\text { Criterion: } 7 \\
\text { X15 } \\
\end{array}$ & $\begin{array}{c}\text { Criterion :8 } \\
\text { X6 } \\
\end{array}$ & $\begin{array}{c}\text { Criterion 9: } \\
\text { X17 } \\
\end{array}$ \\
\hline $\begin{array}{c}\text { Services } \\
\text { structure and } \\
\text { quality inside } \\
\text { LMS } \\
\end{array}$ & $\begin{array}{l}\text { Capability of } \\
\text { System error } \\
\text { tracking }\end{array}$ & $\begin{array}{c}\text { Easy } \\
\text { Accessibility of } \\
\text { system and } \\
\text { communication }\end{array}$ \\
\hline
\end{tabular}

The highest ten ranking criteria by applying Dempster on decision tree and SVM methods are x11, x9, x16, x10, x7, $\mathrm{x} 14, \mathrm{x} 3, \mathrm{x} 8, \mathrm{x} 1, \mathrm{x} 5$ in a ranked way. Then apply Dempster on second iteration with the results of iteration one with multilayer perception weights on the second iteration. Then apply Dempster on the results of the second iteration with gene programming method results in third iteration. The final iteration works on third iteration results with radial basis function weights and obtaining the final highest ten ranking criteria effect on British

\begin{tabular}{|c|c|c|}
\hline $\begin{array}{c}\text { Criterion :1 } \\
\text { X2 }\end{array}$ & $\begin{array}{c}\text { Criterion :2 } \\
\text { X3 }\end{array}$ & $\begin{array}{c}\text { Criterion :3 } \\
\text { X5 }\end{array}$ \\
\hline $\begin{array}{l}\text { Easy using } \\
\text { technology and } \\
\text { attitude of both } \\
\text { students and } \\
\text { instructors } \\
\text { toward } \\
\text { technology }\end{array}$ & $\begin{array}{c}\text { Easy } \\
\text { accessibility } \\
\text { in LMS }\end{array}$ & $\begin{array}{l}\text { Degree of } \\
\text { instructor's } \\
\text { responsiveness } \\
\text { toward } \\
\text { entering } \\
\text { grades on time }\end{array}$ \\
\hline $\begin{array}{c}\text { Criterion :4 } \\
\text { X16 }\end{array}$ & $\begin{array}{c}\text { Criterion :5 } \\
\text { X1 }\end{array}$ & $\begin{array}{c}\text { Criterion :6 } \\
\text { X11 }\end{array}$ \\
\hline $\begin{array}{c}\text { Degree of } \\
\text { instructor's } \\
\text { responsiveness }\end{array}$ & $\begin{array}{l}\text { Easy using } \\
\text { technology } \\
\text { and attitude } \\
\text { of both } \\
\text { students and } \\
\text { instructors } \\
\text { toward } \\
\text { technology }\end{array}$ & $\begin{array}{c}\text { Degree of } \\
\text { interactive } \\
\text { coursers and } \\
\text { its structure }\end{array}$ \\
\hline $\begin{array}{c}\text { Criterion :7 } \\
\text { X7 }\end{array}$ & $\begin{array}{c}\text { Criterion :8 } \\
\text { X9 }\end{array}$ & $\begin{array}{c}\text { Criterion :9 } \\
\text { X12 }\end{array}$ \\
\hline $\begin{array}{c}\text { Easy } \\
\text { accessibility of } \\
\text { system and } \\
\text { communication }\end{array}$ & $\begin{array}{l}\text { Services } \\
\text { quality }\end{array}$ & $\begin{array}{c}\text { Teaching } \\
\text { effectiveness }\end{array}$ \\
\hline $\begin{array}{c}\text { Criterion :10 } \\
\text { X15 }\end{array}$ & \multicolumn{2}{|c|}{$\begin{array}{l}\text { The same as criterion } 8: \\
\text { services quality measure }\end{array}$} \\
\hline
\end{tabular}
university LMS according to the satisfaction of instructors and students as show in table 4 .

Table 4: Results of final iteration of Dempster, first ten ranking criteria effect on BUE LMS

\subsubsection{Applying Dempster on Helwan university LMS.}

Applying equation 1 of Dempster theory on results of Helwan university as the same British university and obtaining the final highest ten ranking criteria effect on

Helwan university LMS according to the satisfaction of instructors and students.
Table 5: Results of final iteration of Dempster, first ten ranking criteria effect on Helwan LMS

\section{DISCUSSION}

According to results obtained from applying artificial intelligence methods and Dempster-Shafer theory on the British university LMS as shown in table 4: The first criterion identifies the positive relationship between communication dimension and (students and instructor's satisfaction). Results prove that communication dimension has the greatest effect on achieving high satisfaction of students and instructors inside BUE university. The second criterion result is the same as the fourth criterion identifies the positive relation between instructor's responsiveness about entering grades on time and learner's satisfactions. This result verifying both relation 2 and 7 in figure 1 and it is in parallel with literature where SevgiOzkan (2009) stated that strong relationship between the instructor's responsiveness toward learner's satisfaction. The third criterion result identifies the positive relation between services quality of interactive courses with learner's satisfaction. These 
results verified relation 3 in figure 1 that shows that students are highly satisfied with the services provided by the administrative team. The fifth criterion identifies positive relationships between capability of LMS error tracking and handling with a degree of satisfaction of students and instructors; this is in parallel with literature where (Volery \& Lord, 2000) stated that student's satisfaction is positively related to the capability of service provided to follow up student problems to solve it.

According to results obtained from Helwan University LMS, the first criterion identifies the positive relationship between ease using of technology used in building LMS and attitude of students and instructors toward technology with the level of satisfaction for both of them. This result verifies relations 1 and 4 in figure 1 also in parallel with the literature where (Webster and Hackley (1997) ) stated that learner's attitudes towards technology have a significant effect on the success of the LMS. The second criterion identifies the strong relationship between the level of accessibility and finding course's materials easily inside LMS and satisfaction of students. The third and fourth criteria identify positive relationships between the degree of instructor's responsiveness and satisfaction level of students as the results of the second criterion on BUE results show. The fifth criterion is same as the second criterion in identifying strong relations between the attitude of using technology and a level of student's satisfaction.

According to results obtained about the highest criteria effect on British and Helwan LMS as shown in tables $(4,5)$ and its relations as shown in figure 1: There are existing relations verified and some relations not verified; there are new relations are proved as well. Relations 1 and 4 in figure 1 are verified through Helwan university results and relations 2,3 and 7 in figure 1 are verified through the British university results. Research results also proved that there is a significant relationship between different criteria that doesn't exist before. BUE results prove that there is a great relationship between communication dimension with satisfaction of students and instructors. Also, through $\mathrm{HU}$ there is positive relationship between the degree of accessibility of LMS and easily fining any material's needed and satisfaction of students.

According to results obtained from two different LMS on different two universities with different natures and methodology of learning, there are similar results on both two universities. There are two common criteria within first five criteria effecting on LMS universities which are $\mathrm{x} 5, \mathrm{x} 16$ that represent responsiveness and availability of instructors which verifies relation 2 in figure 1 . These results proved the importance of these criteria for both two universities, according to achieving high satisfaction for students and instructors. Despite this similarity, there are some differences as a result of the nature of the learning environment. Technology dimension is forbidden from BUE results and exist in HU results. This means that the main focus of students and instructors on BUE are the quality of services and effectiveness of content with qualified instructors. On the other hand, system and the service quality dimension is forbidden from $\mathrm{HU}$ results and exist on BUE results. This indicates that students on $\mathrm{HU}$ are interested in easy using of an LMS with qualified instructors and material content.

\section{CONCLUSION AND FUTURE WORK}

This research attempts to propose an e-learning management system evaluation model consisting of 17 criteria inside six dimensions associated with e-learning systems in Egyptian universities. These criteria are measured through survey instrument questionnaire and check the validity of the

questions based on meeting discussion with a group of experts. Then demonstrates which were critical factors for e-learning system's effectiveness. Even though the statistical analyses applied on data captured to determine reliability of data and deleting outlier of data. Then start determining importance of each factor, according to the satisfaction of students and instructors by using a set of collective of artificial intelligence methods and Dempster Shafer theory. In conclusion, 17 criteria collected under six dimensions and evaluated by applying questionnaires consist of 27 questions as shown in appendix B and determine the most important ten criteria that effect on LMS based on literature survey on factors effect on elearning system inside an Egyptian university environment. That lead us better understand of the needs and requirements of students and instructors. However, this model is not a fixed model. Future research may extend this evaluation model through adding other dimensions or criteria in parallel with changes in the elearning field with the latest update of learning management system technology. And also applying other methods of artificial intelligence or data mining methods with collecting big data by using quantitative or qualitative ways.

Appendix (A): Multidimensional Evaluation Criteria Of Lms Inside Egyptian Universities.

\begin{tabular}{|c|c|c|}
\hline $\begin{array}{c}\text { Evaluation } \\
\text { dimension }\end{array}$ & Criteria & $\begin{array}{c}\text { Question } \\
\text { Number }\end{array}$ \\
\hline $\begin{array}{c}\text { Technology } \\
\text { dimension }\end{array}$ & $\begin{array}{c}\text { Easy use Of } \\
\text { technology }\end{array}$ & $\mathrm{x} 1, \mathrm{x} 2$ \\
\cline { 2 - 3 } & $\begin{array}{c}\text { Accessibility } \\
\text { of System }\end{array}$ & $\mathrm{x} 3, \mathrm{x} 4, \mathrm{x} 7$ \\
\hline \multirow{2}{*}{$\begin{array}{c}\text { System and } \\
\text { service } \\
\text { quality } \\
\text { dimension }\end{array}$} & $\begin{array}{c}\text { Structure of } \\
\text { services }\end{array}$ & $\begin{array}{c}\text { System error } \\
\text { tracking }\end{array}$ \\
\cline { 2 - 3 } & $\begin{array}{c}\text { Service } \\
\text { quality }\end{array}$ & $\mathrm{x} 9, \mathrm{x} 6, \mathrm{x} 15, \mathrm{x} 18, \mathrm{x} 19, \mathrm{x} 21, \mathrm{x} 22$ \\
\hline
\end{tabular}

\begin{tabular}{|c|c|c|}
\hline $\begin{array}{c}\text { Evaluation } \\
\text { Dimension }\end{array}$ & Criteria & $\begin{array}{c}\text { Question } \\
\text { Number }\end{array}$ \\
\hline \multirow{4}{*}{$\begin{array}{c}\text { Effectiveness } \\
\text { of Content } \\
\text { dimension }\end{array}$} & $\begin{array}{c}\text { Interactive } \\
\text { courses }\end{array}$ & $\begin{array}{c}\mathrm{x} 9-\mathrm{x} 10- \\
\mathrm{x} 11-\mathrm{x} 23\end{array}$ \\
\cline { 2 - 3 } & $\begin{array}{c}\text { Course } \\
\text { structure }\end{array}$ & $\mathrm{x} 11, \mathrm{x} 17$ \\
\cline { 2 - 3 } & $\begin{array}{c}\text { Up to date } \\
\text { material }\end{array}$ & $\mathrm{x} 25-\mathrm{x} 26$ \\
\cline { 2 - 3 } & $\begin{array}{c}\text { Entire grade on } \\
\text { time }\end{array}$ & $\mathrm{x} 5, \mathrm{x} 26$ \\
\cline { 2 - 3 } & $\begin{array}{c}\text { Online tests \& } \\
\text { quizzes }\end{array}$ & $\mathrm{x} 13-\mathrm{x} 24$ \\
\hline
\end{tabular}




\begin{tabular}{|c|c|c|}
\hline $\begin{array}{c}\text { Communication } \\
\text { Dimension }\end{array}$ & $\begin{array}{c}\text { Broadband } \\
\text { connection }\end{array}$ & $\mathrm{x} 7, \mathrm{x} 8$ \\
\cline { 2 - 3 } & $\begin{array}{c}\text { Download } \\
\text { material }\end{array}$ & $\mathrm{x} 7, \mathrm{x} 8$ \\
\hline \multirow{3}{*}{$\begin{array}{c}\text { Instructor } \\
\text { Dimension }\end{array}$} & $\begin{array}{c}\text { Teaching } \\
\text { effectiveness }\end{array}$ & $\begin{array}{c}\mathrm{x} 5, \mathrm{x} 11, \\
\mathrm{x} 12, \mathrm{x} 25\end{array}$ \\
\cline { 2 - 3 } & Responsiveness & $\begin{array}{c}\mathrm{x} 5, \mathrm{x} 16, \\
\mathrm{x} 25\end{array}$ \\
\cline { 2 - 3 } & $\begin{array}{c}\text { Attitude toward } \\
\text { technology }\end{array}$ & $\mathrm{x} 1, \mathrm{x} 2$ \\
\hline \multirow{2}{*}{$\begin{array}{c}\text { Student } \\
\text { Dimension }\end{array}$} & $\begin{array}{c}\text { Students } \\
\text { characteristics }\end{array}$ & $\mathrm{x} 14$ \\
\cline { 2 - 3 } & $\begin{array}{c}\text { Attitude toward } \\
\text { technology }\end{array}$ & $\mathrm{x} 1-\mathrm{x} 2$ \\
\hline
\end{tabular}

\section{Appendix (B): Survey Questionnaires}

1. What is opinion about easy use of learning management system?

2. Graphical user interface is suitable for e-learning systems.

3. What degree of finding all educational needs like (learning materials, assignments, etc.)?

4. What Percentage of easy Navigation from course to another inside e-learning system?

5. What degree of Exams and assignment results are announced on time?

6. System capable of frequent updates lecture notes and fixes all the errors and mistakes in the documents.

7. Easley accessing e-learning systems from any network in any places.

8. Download rate or upload rate of materials on elearning system.

9. E-learning system supports high quality video conferencing facility and electronic blackboard for students.

10. The instructors effectively presented the courses using multimedia tools

11. The instructors presented the course content in a well-structured and organized manner and explained concepts clearly.

12. Using case studies and scenarios on uploaded courses for helping gain a clearer content understanding

13. Quizzes appropriately test the materials presented in the courses.

14. What is the degree of managing "study time" effectively and easily complete assignments on time?

15. Quality of The service of contacting with the instructors via mail, phone, fax, chat, forums, discussions and video conferencing etc.

16. The instructors return e-mails/posts within $24 \mathrm{~h}$.

17. Instructors clearly informs the students about grading policy

18. Easily solve problem during admission to a module in registrations.
19. Do not encounter any problems during communicating with university administration and help desk ?

20. Getting immediate feedback by e-mail or telephone If systems crash.

21. Availability of help option on the system 7 days hours.

22. Getting inotifications about all the courses announcements and updating by using 'announcements' tool on LMS

23. Utilizing multimedia tools (Videos-photos-audios) for achieving interactive courses

24. Was there enough variety in the types of quizzes?

25. Courses content and presentations are long enough to cover all content. And up-to-date.

26. Exams and assignment results are announced on time.

27. Percentage of overall quality of British university learning management system.

\section{REFERENCES}

[1] Sevgi Ozkan (2009). Multidimensional students evaluation of e-learning systems in the higher education context: An empirical investigation. Computers \& Education 53 (2009) 1285-1296.

[2] Mohamed attia\& Manal A. Abdel-Fattah \& Sayed Abd El-Gaber (2015). Constructing MultiDimensional Criteria Model for Evaluating Elearning Systems Efficiency in the Higher Educational. International Journal of Advanced Research in Computer Science Volume 5, Issue 1

[3] Shee, D. Y., \& Wang, Y. S. (2008). Multi-criteria evaluation of the web-based e-learning system: A methodology based on learner satisfaction and its applications. Computers Education, 50(3), 894-905 .

[4] Shee, D. Y., \& Wang, Y. S. (2008). Multi-criteria evaluation of the web-based e-learning system: A methodology based on learner satisfaction and its applications. Computers Education, 50(3), 894-905.

[5] Bishop, Christopher M. (2005) Neural Networks for Pattern Recognition. Oxford University Press

[6] Chen, Sheng, Xia Hong and Chris J. Harris, "Orthogonal Forward Selection for Constructing the Radial Basis Function Network with Tunable Nodes", 2005

[7] Cristianini, Nello and John Shawe-Taylor: An Introduction to Support Vector Machines and other kernel-based learning methods. Cambridge University Press, 2000.

[ 8] Orr, Mark J.L. (1966): Introduction to Radial Basis Function Networks, Centre for Cognitive Science, University of Edinburgh, Scotland.

[9] Ferreira, Cândida. Gene Expression Programming. Mathematical Modelling by an Artificial Intelligence, 2nd Edition. Springer-Verlag--Studies in computational intelligence 21, 2006. 
[10] Hsu, C.-W and C.-J. Lin. A comparison of methods for multi-class support vector machines. IEEE Transactions on Neural Networks, 13(2):415-425, 2002.

[11] The Dempster-Shafer Theory of Belief Functions for Managing Uncertainties: An Introduction and Fraud Risk Assessment Illustration Australian Accounting Review, Volume 21, Issue 3, pp. 282-291

[12] Cohen, J. (1988). Statistical power analysis for the behavioral sciences (2nd ed.). Hillsdale NJ: Erlbaum.

[13] Islas, E., Pérez, M., Rodriguez, G., Paredes, I., Ávila, I., \& Mendoza, M. (2007). E-learning tools evaluation and roadmap development for an electrical utility. Journal of Theoretical and Applied Electronic Commerce Research (JTAER), 2(1), 6375

[14] Ahmed Younis Alsabawy, Aileen Cater-Steel, Jeffrey Soar (2013)." IT infrastructure services as a requirement for e-learning system success", Computers \& Education 69 (2013) 431-451

[15] Selim, H. M. (2007). Critical success factors for elearning acceptance: Confirmatory factor models. International Journal of Technology Marketing, 2(2), $157-182$

[16] Khan, B. (2005). Managing e-learning strategies: Design, delivery, implementation and evaluation. Hershey, London, Melbourne, Singapore: Information Science Publishing

[17] Khan, B. (2001). A framework for Web-based learning. Web-based training, 75-98

[18] Shee, D. Y., \& Wang, Y. S. (2008). Multi-criteria evaluation of the web-based e-learning system: A methodology based on learner satisfaction and its applications. Computers Education, 50(3), 894-905.

[19] Ozkan, S., Koseler, R., \& Baykal, N. (2009). Evaluating learning management systems: Adoption of hexagonal e-learning assessment model in higher education. Transforming Government: People, Process and Policy, 3(2), 111-130.

[20] Liaw, S. S., Huang, H. M., \& Chen, G. D. (2007). Surveying instructor and learner attitudes toward elearning. Computers Education, 49(4), 1066-1080.

[21] Douglas, E., \& Van Der Vyver, G. (2004). Effectiveness of e-learning course materials for learning database management systems: An experimental investigation. Journal of Computer Information System, 41(4), 41-48
[22] Dr. goldi puri (2012) critical success factors in elearning - an empirical study. international journal of multidisciplinary research.vol.2 issue 1, January 2012, issn 22315780

[23] Papp, R. (2000). Critical success factors for distance learning. Paper presented at the Americas Conference on Information Systems, Long Beach, CA, USA.

[24] Govindasamy, T. (2001). Successful implementation of e-Learning: Pedagogical considerations. The Internet and Higher Education, 4(3-4), 287-299.

[25] Hollsopple, C., \& Lee Post, A. (2006). Defining, Assessing, and Promoting E Learning Success: An Information Systems Perspective*. Decision Sciences Journal of Innovative Education, 4(1), $67-$ 85.

[26] Sun, P. C. ,Tsai, R. S., Finger, G., Chen, Y-Y., and Yeh, D. (2008) 'What drives a successful eLearning? An empirical investigation of the critical factors influencing learner satisfaction. 'Computers \& Education, 50(4): 1183-1202.

[27]Webster, J., \& Hackley, P. (1997). Teaching effectiveness in technology-mediated distance learning. Academy of Management Journal, 40(6), 1282-1309.

[28] Arbaugh, J. B. (2002). Managing the on-line classroom: A study of technological and behavioural characteristics of web-based MBA courses. Journal of High Technology Management Research, 3, 203 223.

[29] Konradt, U., \& Sulz, K. (2001). The experience of flow in interacting with a hypermedia learning environment. Journal of Educational Multimedia and Hypermedia, 10(1), 69-84.

[30] Collis, B. (1995). Anticipating the impact of multimedia in education: Lessons from the literature. Computers in Adult Education and Training, 2(2), 136-149.

[31] Tazid Ali, Palash Dutta, and Hrishikesh Boruah. A New Combination Rule for Conflict Problem of Dempster-Shafer Evidence Theory. International Journal of Energy, Information and Communications Vol. 3, Issue 1, February, 2012

[32] Volery, T., \& Lord, D. (2000). Critical success factors in online education. The International Journal of Educational Management, 14(5), 216-223. 